\section{Birlesik Dunya Arastrirma Cypriot Journal of Educational BD-CENTER \\ Sciences}

Innovasyon ve Yayıneılık Merkezi
Volume 16 Issue 1 (2021) 221-237

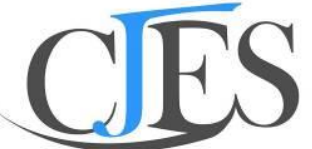

Cypriot Joumal of Educational Sciences

www.cjes.eu

\title{
Developing critical thinking skills towards biology course using two active learning strategies
}

\author{
Raghad Shaher Alsarayreh ${ }^{\mathrm{a}^{*},}$, Al-Balqa' Applied University, Karak University College, Department of Educational \\ and Social Studies, Karak, Jordan https://orcid.org/0000-0003-0258-863X
}

Suggested Citation:

Alsarayreh., S. R. (2021). Teaching Developing critical thinking skills towards biology course using two active learning strategies. Cypriot Journal of Educational Science. 16 (1). 221-237

https://doi.org/10.18844/cjes.v16i1.5521

Received from October 26, 2020; revised from December 29 2020; accepted from January 23, 2021.

${ }^{\circ} 2021$ Birlesik Dunya Yenilik Arastirma ve Yayincilik Merkezi. All rights reserved.

\begin{abstract}
This study aimed to identify the impact of teaching critical thinking skills on the attitude towards biology courses among female students of tenth grade in Jordan using two active learning strategies. To achieve this, the Critical Thinking Scale and the Attitude towards Biology Scale was used, and its validity and consistency were verified. The sample of the study wad (90) female students from the tenth grade in Southern Mazar Directorate in the academic year (2019-2020). The sample of this study was randomly assigned to three groups: the first was experimental group which consisted of (31) students who studied the genetics unit using the directed investigation strategy. The second was the experimental group which consisted of (29) students who studied the genetics unit using the discussion strategy, but the control group consisted of (30) students who studied the genetics unit in the usual way. Data were collected and analyzed after implementing the experiment, which lasted for two months. The results showed that there were statistically significant differences in performance on the Critical Thinking Scale and the Attitude towards Biology Scale in favor of the two experimental groups. The study recommended adopting active learning strategies in teaching science courses in general and biology courses, in addition to conducting more studies on active learning strategies with other variables and classrooms.
\end{abstract}

Keywords: active learning, investigation, discussion, critical thinking, attitude towards biology.

\footnotetext{
${ }^{*}$ ADDRESS FOR CORRESPONDENCE: Raghad, Alsarayreh, Al-Balqa' Applied University, Karak University College, Department of Educational and Social Studies, Karak, Jordan
}

E-mail address: Ragad.Sarayreh@bau.edu.jo / Tel.: 00-962-795213285 
Alsarayreh., S. R. (2021). Teaching Developing critical thinking skills towards biology course using two active learning strategies. Cypriot Journal of Educational Science. 16 (1). 221-237 https://doi.org/10.18844/cjes.v16i1.5521

\section{Introduction}

Science is experiencing a wide cognitive revolution in various fields. Learners face huge challenges that forced them to deal with new problems resulted from scientific and technological advances. Thus, the perception of education has changed so that this era is known as the era of the outbreak of the cognitive revolution. The world has become a small village due to the rapid increase in the spread of knowledge through its various means in a way it becomes easy to exchange knowledge from one place to another, and from one community to another. Today knowledge is the most enriching way to build an individual's personality in all its aspects, henceforth, the individual must place himself in the circle of responsibility towards educating himself in the best way. Educators assert that one of the goals of teaching Science is to teach students how to think, not how to memorize a school course, without understanding, comprehending, or applying them in life. Then, to achieve this, teaching Science must focus on helping students acquire the scientific method of thinking or the scientific method of research and thinking, that is focusing on the methods and processes of science (Zaitoun, 2002).

Al-Ahmad (2005) believes that it is no longer sufficient for a teacher to master the scientific material that he teaches. He is no longer just an indoctrinator for knowledge; rather, he has to be a guide, coordinator, encouraging, and catalyst for teaching learners. Moreover, the future of education depends on upgrading the level of the teacher and the advancement of the teaching profession. Therefore, there has become a global interest in providing both the teacher and the learner with active learning methods and their various strategies, since these methods have proven their effectiveness in achieving many educational goals in the countries that have applied them in their educational systems (Paulson \& Faust, 2002).

Among the recent trends in curriculum development and teaching methods is the necessity to shift from the concept of teaching to the concept of learning. The shift from learning based on merely listening to the teacher to active learning based on the positive participation of the learner (UNESCO, 1996).

Science Education for the Future report (1998) published by the Royal College in London, recommended the necessity of developing curricula and courses in a manner that encourages the use of active learning strategies and urges learners to learn through positive active participation, as well as the development of their skills and cognitive aspects (Hindi, 2010). Curriculum designers have been interested in using the latest learning strategies, which are active learning strategies so that they can be relied upon in many academic stages and curriculum development. It contains many strategies that use modern technology, increase competition, interaction, discussion, thinking, and attitude towards the material, so that the student becomes more interested in research and acquiring various mental skills, including critical thinking skills in particular. Active learning strategies help the learner to have a role in various classroom activities instead of his passive role as a recipient of information. This type of learning encourages the student to participate in pupils' interaction through working in groups and asking many different questions about the lesson on a regular and sequential basis (Schrand, 2008). For learning to be active, learners should be engaged in reading, writing, discussing, solving a problem related to what they are learning, or to experimental work. More deeply, active learning requires learners to use their scientific and practical skills to what they learn in an organized manner (Summer 2005). Active learning makes the learner an active participant in the teaching and learning process, responsible for his learning and achieving the goals of education. As well as, a participant in making decisions related to his learning and participant in monitoring his academic progress and assessing his achievements (Kojak, 2005). Jordanian school students seem to be weak when it comes to critical thinking skills. The researcher believes it is very important to teach students the critical thinking skills due to its importance in improving the students' performance in all fields. There is also a scarcity of studies focused on this topic 
Alsarayreh., S. R. (2021). Teaching Developing critical thinking skills towards biology course using two active learning strategies. Cypriot Journal of Educational Science. 16 (1). 221-237 https://doi.org/10.18844/cjes.v16i1.5521

in the Jordanian context and there is a need to conduct more studies to investigate such relationship. Therefore, this study aims at examining the impact of teaching critical thinking skills using two active learning strategies on their attitude towards Biology course.

\section{The Problem of the study and its Questions}

The problem of the study is embodied in the students' weak acquisition of various mental skills, including critical thinking skills and the Attitude towards Biology among tenth-grade female students in Jordan, as a result of using the usual (traditional) method of teaching. To face this problem, the researcher has studied the teaching effectiveness in developing critical thinking skills and the Attitude towards Biology course for female students of tenth grade in Jordan. Therefore, the study attempted to answer the following two questions:

1. What is the teaching effectiveness in developing critical thinking skills in Biology course among female students of tenth grade in Jordan using two active learning strategies?

2. What is the teaching effectiveness in developing the Attitude towards Biology course among female students of tenth grade in Jordan using two active learning strategies?

\section{The importance of the Study and its justification}

1. The authors of the Biology curriculum and those working to develop it may benefit from the results of this study.

2. Teaching using two active learning strategies may lead to the development of critical thinking skills and Attitude towards Biology.

3. This study could contribute to improving the performance of Biology teachers by providing them with a guide to teach the Genetics unit.

\section{The limitations and boundaries of the study}

1. The study is restricted to use only the directed inquiry strategy and the discussion strategy out of the active learning strategies.

2. The study is restricted to teaching the Genetics unit out of the Biology course for the tenth primary grade only.

\section{Procedural Definitions}

Active Learning: "A group of planned procedures and practices including two active learning strategies (investigation, discussion) in addition to some activities and means performed by the tenthgrade students to accomplish educational tasks. It aims to develop the skills of critical thinking skills and Attitude towards Biology through studying Genetics Unit under the condition that the activity of the student is the effective element while the teacher only guides and directs."

Critical thinking: "It is purposeful, contemplative thinking, governed by the rules of logic and reasoning, and it is the product of cognitive and personal features, which is based on accurate observation of facts. It is measured in this study using critical thinking scale modified to Jordanian environment (2000)."

\section{Theoretical Framework}

\section{First: Active Learning}

One of the most important theories is Constructivism theory which beliefs in the ability of the learner to build his knowledge through a series of practices and repetitions in aspects of theoretical and practical education. The learner creates a clear vision of what he is doing and uses the appropriate 
strategy for learning under the guidance of the teacher, so he has new experiences through his possession of previous experiences, so he rebuilds his knowledge by himself and reaches the meanings through his learning and develops his broad scientific capabilities. The activity of the learner is one of the pillars of Piaget's theory, so learning in the School of Piaget is an active process, based on developing previous experiences with new experiences that the learner gets through work and participation. The criterion by which we judge active teaching strategies is not only the apparent work of the teacher but also by providing the learner with the opportunity to build his knowledge more actively and effectively using active learning strategies. Nevertheless, not through the indoctrination that the teacher performs, so the student uses higher mental and practical skills that help to increase his experiences (Askar and AlKuntar, 2005; Zaitoun, 2002).

Zaitoon and Zaitoun (2006) consider Constructivism theory among the theories that support active learning and believe that the learner who uses active learning creates his knowledge, which is stored within him, either individually or socially, through his previous experiences. As well as the links scientific concepts closely related to the previous concepts that he has gained from his experiences, as active learning strategies greatly help him to achieve himself and to strengthen his positive tendencies towards science learning.

In recent years, there has become an increasing interest in using active learning in science teaching, because of its impact on the development of scientific concepts through integration between the use of some of its ways and methods that provide many opportunities and basic roles for the learner through practicing some of the provided experiences and activities. Through it, the learner acquires practical skills that help him to carry out other new activities, and becomes more active and in love with scientific material (Martyn, 2007).

\section{Active learning concept:}

(Lorenzen, 2006) defines active learning as "a style of learning that depends on the self-activity of the learner and his positive participation. The learner searches utilizing a set of scientific activities and processes using a problem-solving method under the supervision, guidance, and evaluation of the teacher. This makes the student active and able to acquire scientific skills and trends, so the learner enjoys with the teacher in what he learns.

Al-Sayed (2009) defines it: "An educational philosophy that depends on the learner's positivity in the educational situation and includes all educational practices and teaching procedures aimed at activating and maximizing the role of the learner. Learning takes place through work, research, and experimentation, while the learner relies on himself in obtaining information, acquiring skills, and forming values and trends. He does not focus on memorization and indoctrination, but rather on developing thinking and the ability to solve problems, teamwork, and cooperative learning."

(Johnson, 2010) defines it: "The process in which learners actively participate in learning. Active learning provides the learner with interesting and enjoyable lectures rather than passive lectures, including methods of discussion, problem-solving, analysis, synthesis, and evaluation."

\section{Active Learning Objectives}

Many researchers (Awwad \& Zamil, 2010; Saadeh et al., 2006, and others) behold that the goals of active learning are embodied in the diversification of appropriate educational activities for students to achieve the desired educational goals. The nature of active learning helps the learner, through the diversity of activities, their large number, and the diversity of their sources and origins, to develop practical and scientific skills. It helps learners discover scientific concepts by dealing with different 
academic subjects with various strategies so that students by themselves or by the direction of the teacher can access many scientific concepts that were not known to them.

Moreover, active learning Encourages students to ask different questions, as the many activities that students do in school, at home, or in the local environment arouse many questions that must be asked to each other or the teacher to understand the topics well, and to increase the creative work of students. The teacher trains the student to acquire skills through activities and experiences so it is easy to apply these skills in a way that enriches students 'acquisition of knowledge, practical skills, and scientific tendencies.

Active learning in its outcome aims that student to have a large balance of knowledge and diverse information in various school and life fields and areas with the acquisition of a lot of research, practical, scientific, motor, social and skills. As well as, the acquisition of scientific tendencies towards the course, accepting responsibility by encouraging learners to participate in the development achievement of the goals of their learning and the responsibility for their learning. Active learning encourages students to participate actively in setting course goals.

The teacher's role in active learning:

Cashion \& Palmieri (2008), Colaruss \& Rouke, (2009), and Badr (2008) described the role of an active teacher during the educational process as follows:

1. Encouraging students and helping them to learn: It increases their level of learning and encourages them to actively learn individually or in groups.

2. Finding a balance between individual and group educational activities.

3. The teacher's role as a trainer for students in active learning while offering exercises and activities inside and outside the classroom to increase their understanding.

4. The teacher's role is not only an observer but also a researcher and documenter of information.

5. The teacher's role is not only a planner for the daily lessons but also working to create the educational environment surrounding the student.

6. The teacher's role is not only as a person who communicates information but also as a person who listens to students and works to motivate and discuss with them multiple concepts, ideas, and opinions.

7. The teacher's role is not only a mentor, mentor, and facilitator, but also a true supporter of the student as a competitor. Inactive learning, the teacher becomes a partner with the student in building knowledge and acquiring concepts, and a competitor in collecting, analyzing, and evaluating them.

8. The teacher's role is not only to preserve social relations but also to motivate and support them.

The role of the learner in active learning:

The role of the learner in active learning is positive, as he is the focus of the educational process, participating in the work system and in setting educational goals for what he will study, and taking the responsibility of teaching himself under the supervision of the teacher. Abu Riach et al. (2011) and Jumaa (2010) identified the learner's role in active learning by the real desire to participate in informal educational experiences through the student's participation in various and varied seminars and visits and appreciating the value of exchanging ideas and opinions with others. The student should realize that the dialogue with his colleagues is an effective educational activity through which views and ideas are exchanged; he should ask his questions in educational situations without hesitation. As well as, he 
should accept advice and suggestions from teachers, interested persons, and specialists based on affection and friendship, seeking to research, explore, investigate and collect analyze, re-read, compare, analyze constructively criticize information. Moreover, the student should apply knowledge, skills, and tendencies he acquires in educational situations and his new life.

\section{Second: critical thinking}

The interest in developing thinking abilities is not recent. However, its roots can be traced back to the (Plato) Academy, the pattern from which modern Western universities have sprung up. Due to the accelerating social change, teachers must reconsider their role and focus on students' learning the skills and attitudes they need in the process of inquiry (Myers, 1993).

Also, the use of critical thinking leads students to monitor their thinking, so that their ideas are more accurate and correct, thus provides them with the opportunity to be trained in making life decisions, and to stand against many destructive thinking factors and habits such as emotional dependence, or intolerance of opinion (Al-Khatib, 1993). The development of critical thinking leads the individual to independence in his thinking, his freedom from dependency, and the formation of an independent objective mind (Ennis, 1987).

Smith (1983) defines critical thinking, as "the different skills required to judge the correctness and accuracy of information received." Whereas Beyer (1985) believes that critical thinking is the determination of the truth and accuracy of knowledge, judging news based on acceptable sources or examining evidence, comparing incidents and news, then concluding. He also believes that critical thinking is a distinct skill because it includes diligence, accuracy, persistence, and objective analysis of any claim of knowledge or belief, as well as, the judgment on its validity. Many educators define it as "the ability to evaluate information and examine opinions, taking into account the different views on the subject under discussion" (Al-Sorour, 1998).

\section{Critical thinking skills:}

In critical thinking, our thinking should be expanded to reach a complete understanding of the situation or event (the issue), this requires multiple skills such as analysis, comparison, interpretation, judgment, classification, arrangement, and the skills of checking and verifying information (Obeidat and Abu Al-Sameed, 2005).

Qattami (2001) suggests that critical thinking is reasonable contemplative thinking that focuses on what the individual believes or what he is performing. Critical thinking includes capabilities and abilities. Capabilities include searching for a clear formula for the topic of the question, searching for reasons; accessing the necessary information; using important resources, and remembering them. As well as it covers trying to stick to the main point, taking into account the whole situation, seeking to open the mind, searching for accuracy when the topic allows this, in addition to walking in an organized manner to solve the problem, no matter how complicated. While critical thinking capabilities use critical thinking abilities, critical thinking includes analyzing the discussion on the topic, asking and answering questions for clarification on the topic.

Facione (1998) in his identification of the skills of critical thinking depends on the agreement of Delphi experts that includes two kinds of skills: Cognitive skills, and emotional skills. Cognitive skills are the core of critical thinking including:

1. Interpretation: It includes the following sub-skills: classification, meaning extraction, and clarification of the meaning. 
Alsarayreh., S. R. (2021). Teaching Developing critical thinking skills towards biology course using two active learning strategies. Cypriot Journal of Educational Science. 16 (1). 221-237 https://doi.org/10.18844/cjes.v16i1.5521

2. Analysis: It includes the following sub-skills: Examining opinions, discovering arguments, and analyzing them.

3. Evaluation: It includes two sub-skills: evaluation of allegations and evaluation of arguments.

4. Inference: It includes the following sub-skills: investigating evidence, guessing alternatives, and reaching conclusions.

5. Explanation: It includes the following sub-skills: Announcing results, justifying procedures, and presenting arguments.

6. Self-Regulation: It includes two sub-skills: self-evaluation and self-correction.

\section{Previous studies}

Ramadan study (2018) aimed at developing the active learning program for building the personality and measuring its effectiveness in developing positive thinking, and of the sevenths grade students in Amman area. The sample consisted of (70) male and female students, and it was divided into two groups: a control group and an experimental group. A positive thinking scale was distributed to verify the indications of validity and consistency and to build an active learning strategies program for building personality. There are no statistically significant differences at the significance level $(\alpha \leq 0.05)$ between the averages of the scores of $7^{\text {th }}$-grade students in the experimental and control groups in the positive thinking posttest attributed to using the training program for active learning.

(Presad \& Badea, 2014) aimed to evaluate the students' learning using teaching methods that employ active learning strategies instead of regular lectures. The sample of the study consisted of (90) the final year students in philosophy major. The results of the study showed that only about $45 \%$ of students know the concept of active learning while the percentage of those who know some active learning strategies is $15 \%$. The percentage of those who find active learning enjoyable as a teaching method was $87 \%$, while the percentage of students who believe that active learning is important and should be used instead of a regular lecture was $63 \%$.

Al-Saoub (2013) conducted a study aimed at identifying the effectiveness of a strategy based on some active learning methods for developing chemical concepts, practical skills, and the attitude towards chemistry among tenth-grade students in Jordan. The study sample consisted of (137) male and female students of the tenth grade in Jordan, it was distributed to two groups. The experimental one consisted of (70) male and female students whereas the control group consisted of (67) male and female students. The experimental group was taught using the proposed strategy based on some active learning methods while the experimental group was taught in the usual way. To verify the objectives of the research, the following research tools were built: testing of chemical concepts, the observation card of practical skills, and the attitude towards chemistry. The results of the research showed the effectiveness of the proposed strategy based on some active learning methods in developing chemical concepts, practical skills, and the attitude towards chemistry in the post-test in favor of the experimental group.

Judy's study (2012) aimed to investigate the effect of employing some active learning strategies in teaching science on the development of life skills among fourth-grade students in the Gaza governorate. The researcher built a life skills test and prepared a guide for teaching the unit of the human body through active learning strategies. The results of the study showed that the experimental group was statistically significantly better in the life skills test.

Ruff (2005) conducted a study that examines whether infusing explicit critical thinking instruction into the course of a first-year transition can accelerate the critical thinking development of first-year 
college students. The focus of this study was critical thinking pedagogy and the impact of this instruction on a class of students. Students in both sections were administered the California Critical Thinking Skills Test (CCTST) in a pretest-posttest design during the second and final class meetings. Independent samples t-test and ANOVA test were used to analyze data collected. The findings demonstrated that females and males in the experimental group outperformed their peers in the control group. Moreover, there was some indication that females in the experimental group might have benefited from the treatment more than the males.

Abdul Razzaq's study (2001) aimed to investigate the effect of using the constructivism method in the Biology laboratory on student achievement and their development of critical thinking. The study population consisted of the first-year students at the Faculty of Science, Al-Quds University, for the academic year (2001-2000) that was (355) students. The study sample consisted of (61) male and female students. California Critical Thinking Skills Test (CCTST) was used to measure the level of critical thinking skills. The study revealed that there are discrepancies in the averages of students' performance in critical thinking skills tests (Total degree and the dimensions of analysis and conclusion) attributed to the method of teaching. As well as the study revealed that there are no differences in the averages of students' performance in critical thinking skills pretest-posttest using constructivism method and in the averages of critical thinking skills level (total degree), neither of its dimensions attributed to gender nor any of its dimensions attributed to the interaction of gender and teaching style.

Christianason \& Fisher (1999) conducted a study to compared two groups of students, the first one applied active learning using small discussion groups while the second group adopted teaching in the usual way. The results of the study revealed the effectiveness of active learning in the correct and accurate understanding of the concepts included in the topics of diffusion and absorption included within a unit in the Physics course, as well as, the study recommended further studies on active learning.

\section{Methodology}

The researcher followed the quasi-experimental approach in this study to measure the effectiveness of teaching using two strategies for active learning in developing critical thinking skills and the Attitude towards Biology among tenth-grade female students in Jordan. The individuals of the study sample were selected from the schools affiliated with Education Directorate in Southern Mazar District where they were divided into three groups: the first experimental group was taught with a directed investigation strategy, the second experimental group was taught with a discussion strategy, and the control group was taught traditionally.

\section{The population of the study and its sample}

The population of the study consisted of all tenth-grade students at Education Directorate in Southern Mazar District according to the statistics of the Ministry of Education during the first semester of 2019/2020. The Hussainiya Secondary School for Girls was deliberately chosen, as there is tenth grade three sections in this school. The three sections were assigned randomly to a control group whose number of students reached (30) students, which was taught traditionally. The first experimental group, which was taught by the strategy of directed investigation, with (31) students while the second experimental group, which was taught with the discussion strategy whose number of students reached (29).

\section{The Instruments of the Study}

First: The Critical Thinking Scale

California Critical Thinking Skills Test (CCTST) (2020) was chosen after been modified for the Jordanian environment. The California Critical Thinking Skills Test (CCTST) is designed primarily to assess 
the core critical thinking skills of postsecondary level persons. The California Academic Press published it in 1990. This test has three forms A (1990), B (1992), and C (2000). This test is based on the definition of critical thinking reached by the consensus of experts at the APA Delphi conference (1990). The CCTST reports six scores: an overall score on CT cognitive skills and five sub-scores named analysis, evaluation, inference, deductive reasoning, and inductive reasoning. This test is considered one of the first tests to measure critical thinking whose realistic validity is derived from a comprehensive definition of the concept of critical thinking. APA Delphi experts as representing the main central skills for critical thinking view the three thinking skills (analysis, evaluation, and inference). Therefore, these three skills had subscores on the CCTST. Taking into account that the skill of self-regulation cannot be easily accessed independently apart from other skills, even if it was practiced by the examinee while answering the test. The other two sub-scores on the test are inductive reasoning and inductive reasoning. The test uses a more traditional method of formulating the concepts of logical thinking, in which logical thinking is divided into conclusion and deduction. The thirty-four items of the test are divided into two ways: The first is divided into three sections of the test that measure the three main skills according to the concept of Delphi, namely: analysis, evaluation, inference counted (34) items. The second divides the test items into two parts: items that measure the skill of deduction, and items that measure the skill of induction counted (30) items. The reason for the use of the skills of deduction and induction in the California test because of the frequent use of these skills in studies. Thus, the CCTST has six scores: an overall score for cognitive critical thinking skills and five sub-scores: analysis, evaluation, inference, deduction, and induction (Al-Abdalat, 2003). The validity and reliability of the scale were verified as follows:

The validity of the critical thinking scale

The degree of validity of the scale was evaluated by presenting it to (10) arbitrators from faculty members of Mutah University and Al-Balqa Applied University - Jordan from the departments of Psychology, Curricula, and Teaching Methods of Science. The arbitrators expressed their views on the suitability of the items of the scale to the Jordanian environment as well as the clarity of their linguistic formulation. Their opinions were taken into consideration and the items were modified, reformulated, and corrected when there was $80 \%$ agreement between them. The researcher has done all the required modifications and there was no deletion of any item. So, the total number of the items on the scale equals 34 .

The reliability of scale:

The reliability coefficient of the scale was calculated by the test-retest method, as the scale was applied to an exploratory randomly selected sample consisting of (28) students of the study population but outside the sample. Then, the test was repeated after two weeks and the Pearson correlation coefficient between the two application times was calculated to be (0.84).

\section{Second: Attitude towards Biology Scale}

The dimensions of the Attitude towards Biology scale were prepared by referring to the theoretical literature and previous studies that dealt with developing the Attitude towards Biology course, taking into account the nature of the unit in question, the scale in its initial form consists of (38) items. After it was presented to the arbitrators again, in its final form of (35) items, a 3-point Likert scale was used (agree - not sure - disagree).

The validity and reliability of the scale were verified as follows:

The validity of the Attitude towards Biology scale

The degree of validity of the scale was evaluated by presenting it to (10) arbitrators from faculty members of Mutah University and Al-Balqa Applied University - Jordan from the departments of 
Psychology, Curricula, and Teaching Methods of Science. The arbitrators expressed their views on the suitability of the items of the scale to the Jordanian environment as well as the clarity of their linguistic formulation. Their opinions were taken into consideration and the items were modified, reformulated, and corrected when there was $80 \%$ agreement between them. The researcher has done all the required modifications and three items were deleted. Therefore, the total number of the items of the scale equals 35 and the estimation was considered to be scaled $(3,2,1)$ for positive and $(1,2,3)$ for negative statements.

The reliability of scale:

The reliability coefficient of the scale was calculated using internal consistency (Cronbach's Alpha), as the scale was applied to an exploratory randomly selected sample consisting of (28) students of the study population but outside the sample. Cronbach's Alpha test was calculated to be $(0.90)$ that is acceptable for the study.

Preparation of teacher guide for genetics unit.

The guide includes the following:

- Introduction to the guide: The introduction to the guide explained the importance of active learning and how to teach using active learning (investigation, discussion), and encouraged the students to use their mental capabilities in solving their problems in addition to facing different life situations imposed by the nature of the current era.

- Teaching the genetics unit: The genetics unit topics were prepared according to the two strategies for active learning (investigation, discussion), and the teacher's guide included the general objectives of teaching biology that was identified in this research, which the genetics topics seek to achieve. It also included specific objectives for the topics and procedural goals that were formulated at the beginning of each topic.

- Ensuring the validity of the teacher's guide: The teacher's guide was presented to several arbitrators specialized in curriculum development at the Jordanian Ministry of Education with Biology specialty and several specialists from faculty members at Mutah University and Al-Balqa Applied University (Department of Curricula and Science Teaching Methods those who previously participated in the development of science curricula in general and biology curricula in particular, to identify their views on the following matters:

a. The Achievement of the guide of the objectives of the proposed unit from the proposed perspective of the Biology curriculum.

b. Some arbitrators suggested modifying some behavioral goals.

c. The diversity of teaching ways and methods used in the teacher's guide.

d. The diversity of evaluation ways and methods used in the teacher's guide.

e. Scientific accuracy in planning lessons according to the proposed mental processes.

f. Appropriateness of the form and content of the teacher's guide and the method of preparing it with what the educational literature recommends.

g. The opinion of the arbitrators in arranging the goals according to their cognitive, skill, and emotional axes.

Based on the observations made by the arbitrator, the researcher made the necessary adjustments in the teacher's guide. 
Alsarayreh., S. R. (2021). Teaching Developing critical thinking skills towards biology course using two active learning strategies. Cypriot Journal of Educational Science. 16 (1). 221-237 https://doi.org/10.18844/cjes.v16i1.5521

\section{Study variables}

The independent variable:

Teaching methods and it has three categories (investigation teaching method, discussion teaching method, traditional teaching method).

Dependent variables:

- Critical thinking: It is measured by the student's degree on the scale adopted by the researcher for this study.

- Attitude towards Biology: It is measured by the student's degree on the scale adopted by the researcher for this study.

\section{Study design}

The researcher used the quasi-experimental design for two experimental and control groups as follows:

$$
\begin{aligned}
& \begin{array}{llllll}
\mathrm{G}_{\mathrm{E} 1} & \mathrm{O}_{1} \mathrm{O}_{2} & \mathrm{X}_{1} & \mathrm{O}_{3} \mathrm{O}_{4}
\end{array} \\
& \begin{array}{llllll}
\mathrm{G}_{\mathrm{E} 2} & \mathrm{O}_{1} \mathrm{O}_{2} & \mathrm{X}_{2} & \mathrm{O}_{3} \mathrm{O}_{4}
\end{array} \\
& \begin{array}{lllll}
\mathrm{G}_{\mathrm{C}} & \mathrm{O}_{1} \mathrm{O}_{2} & - & \mathrm{O}_{3} \mathrm{O}_{4}
\end{array}
\end{aligned}
$$

Where:

$\left(G_{E 1}\right)=$ Experimental group 1

$\left(\mathrm{G}_{\mathrm{E} 2}\right)=$ Experimental Group 2.

$\left(G_{c}\right)=$ Control Group.

$\left(\mathrm{O}_{1}\right)=$ a pre-test measure of critical thinking.

$\left(\mathrm{O}_{2}\right)=$ pre-test measure of Attitude towards Biology.

$\left(\mathrm{O}_{3}\right)=$ post-test measure of Critical Thinking.

$\left(\mathrm{O}_{4}\right)=$ post-test measure of the orientation towards biomaterial.

$\left(X_{1}\right)=$ indicates experimental treatment (investigation teaching).

$\left(X_{2}\right)=$ indicates experimental treatment (discussion teaching).

\section{Study application procedures}

The study steps were carried out as follows:

1) The study population and its sample were identified.

2) A teaching plan was prepared according to the teaching procedures using active learning (investigation, discussion).

3) The teaching plan was presented to several specialists with experience in the field of curricula and teaching methods as well as academics in psychology, specialists in curriculum development in the Jordanian Ministry of Education, educational directors and specialists in the Ministry of Education, and professors of Biology. The amendments they referred to were made and finalized.

4) The official approvals were taken from the assigned authorities to implement the study. 
5) Applying pre-test of the scale of critical thinking skills standardized for the Jordanian environment (California test for critical thinking), and the Attitude towards Biology Measure to the study groups.

6) The approved teaching plan was implemented, whereby the two experimental groups studied using the active learning method (investigation, discussion), while the control group studied according to the traditional method by the same teacher, with the full supervision of the researcher.

7) Post-test of Critical Thinking Skills Scale and the Attitude towards Biology post-test were applied after completing the teaching of the specific subject on the study groups.

8) The critical thinking scale and the Attitude towards Biology scale were corrected. Data was entered into the computer and the study questions were answered.

\section{Statistical Analysis}

To answer the first and second study questions, (ANCOVA) test was used.

\section{Results}

\section{First Question Results}

To answer the first study question stating "What is the teaching effectiveness in developing critical thinking skills in Biology course among female students of tenth grade in Jordan using two active learning strategies?" ANCOVA test was used. The results are shown in Table 1 that demonstrates the arithmetic averages and standard deviations of the performance of the female students measured by critical thinking scale (pre-test $\&$ post-test) regarding study groups.

Table 1. Arithmetic Averages and Standard Deviations of Students' Performance on Critical Thinking Scale according to the Group

\begin{tabular}{|c|c|c|c|c|c|}
\hline \multirow[b]{2}{*}{ Group } & \multicolumn{2}{|c|}{ Pre-test } & \multicolumn{3}{|c|}{ Post-test } \\
\hline & Average & S.D. & Average & S.D. & $\begin{array}{c}\text { Modified } \\
\text { Arithmetic } \\
\text { Average }\end{array}$ \\
\hline $\begin{array}{l}1^{\text {st }} \text { experimental group } \\
\text { (investigation) }\end{array}$ & 12.26 & 2.46 & 28.09 & 1.79 & 28.05 \\
\hline $\begin{array}{c}2^{\text {ed }} \text { experimental group } \\
\text { (discussion) }\end{array}$ & 11.83 & 2.52 & 27.37 & 2.09 & 27.37 \\
\hline Control Group (traditional) & 11.03 & 2.32 & 18.83 & 1.76 & 18.88 \\
\hline
\end{tabular}

Table 1 shows that the arithmetic average of the study sample's performance on the pre-test Critical Thinking Skills scale for the first experimental group (investigation) was (28.09) with a standard deviation of (1.79), while the arithmetic average of the second experimental group (discussion) was (27.37) with a standard deviation of (2.09). As for the (traditional) control group, its arithmetic average was (18.83) with a standard deviation of (1.76). To identify the significance of the statistical difference between the arithmetic means, (ANCOVA) test was used, Table (2) illustrates the results. 
Alsarayreh., S. R. (2021). Teaching Developing critical thinking skills towards biology course using two active learning strategies. Cypriot Journal of Educational Science. 16 (1). 221-237 https://doi.org/10.18844/cjes.v16i1.5521

Table 2. one-way ANCOVA (analysis of covariance) of the Effect of the Group on the Critical Thinking (post-test)

$\begin{array}{ccccccc}\text { Source } & \text { Sum of Squares } & \mathrm{df} & \begin{array}{c}\text { Mean } \\ \text { Squares }\end{array} & F & \text { Sig. } & \begin{array}{c}\text { Partial Eta } \\ \text { Squared }\end{array} \\ \text { Pre } & 2.986 & 1 & 2.986 & 0.837 & 0.363 & 0.831 \\ \text { group } & 1506.987 & 2 & 753.493 & 211.270 & 0.000 & \\ \text { Error } & 306.718 & 86 & 3.566 & & & \\ \text { Total } & 57162.000 & 90 & & & & \\ \text { Corrected Total } & 1907.556 & 89 & & & & \end{array}$

It is evident from Table 2 that there are statistically significant differences in performance on the Critical Thinking Skills Scale (post-test) attributed to the group since the value of $(P)(211,270)$ is statistically significant at the $(\alpha=0.05)$. Also, Partial Eta Squared reached (83.1). To identify the source of the differences, the Bonferroni test for post-test comparisons was used as shown in Table 3.

Table 3. Post-Test Result of Bonferroni test for Critical Thinking

$\begin{array}{lccc}\text { Group } & \begin{array}{l}1^{\text {st }} \text { experimental group } \\ \text { (investigation) }\end{array} & \begin{array}{l}2^{\text {ed }} \text { experimental group } \\ \text { (discussion) }\end{array} & \begin{array}{c}\text { Control Group } \\ \text { (traditional) }\end{array} \\ 1^{\text {st }} \text { experimental } \quad \text { (investigation) } & - & 0.685 & 9.17^{*} \\ (28.09) & - & - & 8.48^{*} \\ 2^{\text {ed }} \text { experimental (27.37) } & - & - & - \\ \text { Control (traditional) (18.83) } & & \end{array}$

Table 3 indicates that the difference between the arithmetic average of critical thinking of the students of the first experimental group (investigation) and that of the second experimental group (discussion) is statistically insignificant (0.685). Whereas, the difference between the arithmetic average of critical thinking of the students of the first experimental group (investigation) and that of the control group (traditional) is statistically significant (9.17). As well, the difference between the arithmetic average of critical thinking of the students of the first experimental group (investigation) and that of the control group (traditional) is statistically significant (8.48). Henceforth, the differences in critical thinking skills are attributed favorably to the two experimental groups (investigation and discussion).

This result may be attributed to:

1. The use of the two active learning (investigation, discussion) strategies provided a constructive learning environment and opened up broad horizons of educational experiences for students to benefit from them. As well as making the students a basic pivot in the educational learning process, where the student's role changed from recipient to researcher relying on himself in cooperation with his teacher and colleagues that helped to develop the students' critical thinking skills.

2. The two active learning (investigation, discussion) strategies contributed to training students in various classroom, extra-curricular activities, field visits, and practical experiments.

\section{Second Question Results}

To answer the second question stating "What is the teaching effectiveness in developing Attitude towards Biology course among female students of tenth grade in Jordan using two active learning strategies?" One-way ANCOVA (analysis of covariance) was used. Table 4 the arithmetic averages and 
Alsarayreh., S. R. (2021). Teaching Developing critical thinking skills towards biology course using two active learning strategies. Cypriot Journal of Educational Science. 16 (1). 221-237 https://doi.org/10.18844/cjes.v16i1.5521

standard deviations of the performance of the female students measured by the Attitude towards Biology scale (pre-test $\&$ post-test) regarding study groups.

Table 4. Arithmetic Averages and Standard Deviations of Students' Performance on Attitude towards Biology according to the Group

\begin{tabular}{|c|c|c|c|c|c|}
\hline Group & Average & S.D. & Average & S.D. & $\begin{array}{l}\text { Modified } \\
\text { Arithmetic } \\
\text { Average }\end{array}$ \\
\hline $\begin{array}{l}1^{\text {st }} \text { experimental group } \\
\text { (investigation) }\end{array}$ & 49.45 & 6.45 & 91.74 & 4.47 & 91.75 \\
\hline $\begin{array}{l}2^{\text {ed }} \text { experimental group } \\
\text { (discussion) }\end{array}$ & 51.14 & 6.03 & 92.59 & 4.87 & 92.58 \\
\hline Control Group (traditional) & 49.87 & 7.53 & 69.93 & 5.58 & 69.94 \\
\hline
\end{tabular}

Table 4 shows that the arithmetic average of the study sample's performance on the pre-test Attitude towards Biology scale for the first experimental group (investigation) was (91.74) with a standard deviation of (4.47), while the arithmetic average of the second experimental group (discussion) was (92.59) with a standard deviation of (4.87). As for the (traditional) control group, its arithmetic average was (69.93) with a standard deviation of (5.58). To identify the significance of the statistical difference between the arithmetic means, (ANCOVA) test was used, Table (5) illustrates the results.

Table 5. one-way ANCOVA (analysis of covariance) of the Effect of the Group on the Attitude towards Biology (post-test)

\begin{tabular}{|c|c|c|c|c|c|c|}
\hline Source & Sum of Squares & $d f$ & Mean Squares & $\mathrm{F}$ & Sig. & $\begin{array}{c}\text { Partial Eta } \\
\text { Squared }\end{array}$ \\
\hline Pre & 0.295 & 1 & 0.295 & 0.012 & 0.914 & \\
\hline group & 9868.872 & 2 & 4934.436 & 195.870 & 0.000 & 0.82 \\
\hline Error & 2166.541 & 86 & 25.192 & & & \\
\hline Total & 658395.000 & 90 & & & & \\
\hline Corrected Total & 12049.122 & 89 & & & & \\
\hline
\end{tabular}

It is evident from Table 5 that there are statistically significant differences in performance on the Attitude towards Biology scale (post-test) attributed to the group since the value of (P) (195.870) is statistically significant at the $(\alpha=0.05)$. Also, Partial Eta Squared reached $(0.82)$. To identify the source of the differences, the Bonferroni test for post-test comparisons was used as shown in Table 6 .

Table 6. Post-Test Result of Bonferroni test for Attitude towards Biology

$\begin{array}{lccc}\text { Group } & \begin{array}{l}1^{\text {st }} \text { experimental group } \\ \text { (investigation) }\end{array} & \begin{array}{l}2^{\text {ed }} \text { experimental group } \\ \text { (discussion) }\end{array} & \begin{array}{c}\text { Control Group } \\ \text { (traditional) }\end{array} \\ 1^{\text {st }} \text { experimental } \quad \text { (investigation) } & - & 0.83 & 21.81^{*} \\ (28.09) & - & - & 22.64^{*} \\ 2^{\text {ed }} \text { experimental (27.37) } & - & - & - \\ \text { Control (traditional) (18.83) } & & \end{array}$


Table 6 indicates that the difference between the arithmetic average of Attitude towards Biology of the students of the first experimental group (investigation) and that of the second experimental group (discussion) is statistically insignificant (0.83). Whereas, the difference between the arithmetic average of Attitude towards Biology of the students of the first experimental group (investigation) and that of the control group (traditional) is statistically significant (21.81). As well, the difference between the arithmetic average of Attitude towards Biology of the students of the first experimental group (investigation) and that of the control group (traditional) is statistically significant (22.64). Henceforth, the differences in Attitude towards Biology is attributed favorably to the two experimental groups (investigation and discussion). The results of the present study showed that there were statistically significant differences in performance on the Critical Thinking Scale and the Attitude towards Biology Scale in favor of the two experimental groups. These results are consistent with Ruff (2005) and Judy (2012) who found a significant impact of critical thinking instruction on the development of students' performance in critical thinking. This result may be attributed to the two active learning strategies (investigation, discussion) provided a constructive learning environment and opened broad horizons educational experiences for students to benefit from and made the students a basic focus in the educational learning process, where the student's role changed from recipient to self-reliant researcher in cooperation with his teacher and colleagues. This leads to an improved Attitude of the students towards Biology. It is obvious that teaching critical thinking for students would play a vital role in improving the students' performance in this skill. Students need critical thinking especially in the scientific courses in order to succeed and cope with their academic life.

\section{Conclusion}

The present study aims at examining the effect of teaching critical thinking skills on the students' performance and attitude in Biology course among Jordanian school students. The results revealed a significant effect of both the independent and dependent variables. The students showed positive attitude towards Biology course after receiving the necessary instruction towards critical thinking. These results would have some pedagogical implications; first, it is necessary to include the critical thinking instruction in the curriculum of science courses. Second, Curriculum designers would be in a better position to understand the attitudes of students towards critical thinking and design a better curriculum based on those attitudes. The teachers would also be in a good position on how to deal with students when it comes to critical thinking; they would employ the appropriate teaching methods when dealing with these skills.

\section{Recommendations}

1. Adopting the various active learning strategies in teaching science curricula in general and biology curricula in particular for all academic levels in Jordan.

2. Conducting more studies on active learning strategies in science curricula in new research variables with other academic classes.

\section{References}

Abdul Razzaq, M. (2001). The effect of using the structural method in the laboratory on student achievement and the development of critical thinking in them. Unpublished MA Thesis, Al-Quds University, Al-QudsPalestine.

Abu Rayyash, H., Sharif, S., \& Safi, A. (2011). Origins of learning and teaching strategies. Jordan: $2^{\text {nd }}$ Edition, House of Culture for Publishing and Distribution. 
Alsarayreh., S. R. (2021). Teaching Developing critical thinking skills towards biology course using two active learning strategies. Cypriot Journal of Educational Science. 16 (1). 221-237 https://doi.org/10.18844/cjes.v16i1.5521

Al-Abdallat, S. (2003). The effect of a training program based on problem learning on developing critical thinking skills among tenth-grade students. Unpublished Ph.D. thesis, Amman Arab University for Graduate Studies, Amman - Jordan.

Al-Ahmad, K. (2005). Training teachers from preparation to training. Emirates: University Book House.

Al-Jadi, M. (2012). The effect of employing some active learning strategies in science teaching on developing life skills among fourth-grade students in Gaza Governorate. Unpublished MA Thesis, Al-Azhar University Gaza.

Al-Khatib, M. (1993). The effect of each of the degrees of cognitive independence, achievement, and gender on the ability of critical thinking for the age group (11-14) in public schools for the first Amman region. Unpublished MA thesis, University of Jordan, Amman-Jordan.

Al-Said. J. (2009). Active learning. Education Magazine, National Center for Educational Research and Development, No. 53, Spring. P. 29.

Alsaifi, A. (2005). Teacher and Modern Learning Strategies. Cairo: Osama House for Publishing and Distribution.

Askar, A., \& Al-Qantar, F. (2005). An introduction to educational psychology from a major perspective. Kuwait: First Edition, Al Falah Library.

Awad, Y., \& Zamil, M. (2010). Active learning towards an effective educational philosophy. Jordan: House of Curriculum for Publishing and Distribution.

Badr, K. (2008). Active learning. Jordan: T, 1 Dar Al Masirah for Publishing, Distribution, and Printing.

Difficult T. (2013). Strategic effectiveness is based on some active learning methods to develop chemical concepts, practical skills, and inclination towards chemistry among tenth-grade students in Jordan. Unpublished Ph.D. thesis, Institute of Educational Studies, Cairo University.

Juma'a, S. (2010). Active Learning Strategies. The project of applied aspects of scientific methods and research in curricula and teaching methods in Cairo, Arabic for advanced curricula and software. P. 35.

Kojak, K. (2005). Active Learning Handbook. Cairo: Curriculum and Educational Resource Development Center.

Myers, C. (1993). Teaching students critical thinking (translated by Azmi Jarrar). Amman: Jordan Book Center.

Obeidat, T., \& Abu Semaid, S. (2005). Brain, learning, and thinking. First edition, Oman: Debono Publishing and Distribution.

Pleasure, N. (1998). An introduction to the education of the privileged and talented. First edition, Oman: Dar Al Fikr for Printing, Publishing, and Distribution.

Qatami, N. (2001). Teaching thinking to the primary stage. Thought House for Printing, Publishing and Distribution, Amman - Jordan.

Ramadan, M. (2018). The effect of active learning strategies on positive thinking among seventh-grade students in the Amman region. Journal of the College of Basic Education for Educational and Human Sciences, University of Babylon.

Saadeh, J. (2006). Active learning between theory and practice. Jordan: $2^{\text {nd }}$ Edition, Dar Al Shorouk. Hindi, M. (2010). Active learning is a modern, ancient educational interest. Cairo, Dar Al-Nahda for Publishing and Distribution.

Zaitoun, A. (2002). Teaching science to understand a constructive future vision. First Edition, Cairo: The World of Books.

Zaitoun, K., \& Zaitoun, H. (2006). Learning and teaching from a constructivist theory perspective. Cairo: The World of the Book. Second: References are in English

Beyer, B. K. (1985). Critical Thinking Revisited. Social Education, 49(4), 268-69. 
Alsarayreh., S. R. (2021). Teaching Developing critical thinking skills towards biology course using two active learning strategies. Cypriot Journal of Educational Science. 16 (1). 221-237 https://doi.org/10.18844/cjes.v16i1.5521

Christianson, R. G., \& Fisher, K. M. (1999). Comparison of student learning about diffusion and osmosis in constructivist and traditional classrooms. International Journal of Science Education, 21(6), 687-698.

Johnson, L. S. (2010). Student perceptions of active instructional designs in four inner city adult education math classes. Capella University.

Lorenzen, M. (2001). Active learning and library instruction. Illinois Libraries, 83(2), 19-24.

Presada, Badea (2014). Active and peer learning techniques in literature classes. Journal Plus Education (2), 37-45.

Reavis, L. J. (2009). Art Teacher Preparation for Teaching in an Inclusive Classroom: A Content Analysis of PreService Programs and a Proposed Curriculum.

Ruff, L. G. (2005). The development of critical thinking skills and dispositions in first-year college students: Infusing critical thinking instruction into a first-year transitions course (Doctoral dissertation).

Schrand, T. (2008). Tapping into active learning and multiple intelligences with interactive multimedia: A lowthreshold classroom approach. College Teaching, 56(2), 78-84.

Smith, B. (1993). Instruction for Critical Thinking Skills. The Social Studies, 74(5), p210-212.

UNESCO (1996). Current Issues and Trends in Technical and Vocational Education. Paris No.8. 